\title{
KETERAMPILAN MANAJERIAL KEPALA SEKOLAH DALAM MENGEMBANGKAN BUDAYA RELEGIUS (STUDI KASUS DI SMP NEGERI 7 MATARAM)
}

\author{
Maimun \\ Universitas Islam Negeri (UIN) Mataram \\ Jl. Pendidikan No. 35 Mataram \\ Email:maimun05@ymail.com
}

\begin{abstract}
Abstrak: Kepala sekolah merupakan pemimpin pendidikan yang memiliki peran sentral dalam membawa keberhasilan lembaga pendidikan karena dia berperan memandu, menuntun, membimbing, membangun, memotivasi kerja, mengemudikan organisasi, menjalin jaringan komunikasi yang baik dengan komunitas sekolah, lingkungan sekitar dan yang lainnya.Kepemimpinan sebagai salah satu fungsi manajemen merupakan hal yang sangat penting untuk mencapai tujuan organisasi. ${ }^{1}$ Kepemimpinan adalah suatu kekuatan penting dalam rangka pengelolaan, oleh sebab itu kemampuan memimpin secara efektif (effective leader) merupakan kunci keberhasilan organisasi/sekolah. Hasil penelitian menunjukkan: (1) Realitas budaya releigius yang dikembangkan Kepala Sekolah tercermin melalui nilai-nilai atau norma-norma yang cukup mewarnai aktivitas seluruh komponen sekolah; (2) Keterampilan Konsep kepala sekolah teraplikasi melalui penguatan karakter, yakni memiliki sikap dan prilaku keagamaan yang dicerminkan lewat bekerja maksimal, dan jujur; (3) Keterampilan manusiawi kepala sekolah dalam mengembangkan budaya agama melaui pembiasaan sikap saling pengertian dan saling percaya telah dalam diri warga sekolah, sehingga hubungan baik pun tercipta diantara mereka sekalipun berbeda keyakinan dan kepercayaan dalam agama; (4) Keterampilan Teknik kepala sekolah dalam mengembangkan budaya agama terwujud dari sikap kebersamaan seperti peringatan hari besar agama-agama di SMP Negeri 7 Mataram menjadi salah satu elemen yang dihidupkan oleh Kepala Sekolah dalam mengembangkan budaya religius agar warga sekolah memahami sekaligus menghargai beberapa macam dan model perayaan hari besar dari agama-agama yang berbeda; dan (5) Keterampilan Personal kepala sekolah dalam mengembangkan budaya agama terkristalisasi dalam Visi religius yang diemban oleh SMP Negeri 7 Mataram menjadi sebuah keharusan bagi warga sekolah untuk mewujudkannya dalam bentuk budaya religius.
\end{abstract}

\begin{abstract}
The principal is an educational leader who has a central role in bringing the success of an educational institution because he plays a role in guiding, holding, supervising, building, motivating work, steering the organization, establishing a good communication network with the school community, the environment and others. Leadership as one of management functions is very important to achieve organizational goals. Leadership is an important force in the framework of management, therefore, the ability to lead effectively is the key to success of the organization/school. The research results showed: (1) The reality of religious culture developed by the Principal is reflected through the values or norms that adequately color the activity of all school's components; (2) The concept skills of principals is applied through the characters' strengthening that is to have attitudes and religious behaviors reflected through maximum work, and honest; (3) The principal's humanity skill in developing a religious culture through the habit of mutual understanding and mutual trust within the school community, so that good relations are created among them despite their different beliefs in religion; (4) The
\end{abstract}

1 Wahjosumidjo, Kepemimpinan, hlm. 5. 
principal's technical skill in developing the religious culture is manifested from the attitude of togetherness such as the commemoration of religious days in SMP Negeri 7 Mataram became one of the raised elements by the Principal in developing the religious culture so that the school's member understood and appreciated several kinds and models the celebration of the great day of different religions; and (5) The principal's personal skills in developing religious culture is crystallized in the religious vision carried by SMP Negeri 7 Mataram becomes a necessity for the school's member to make it happen in the form of religious culture.

Kata Kunci: keterampilan manajerial, budaya religius

\section{PENDAHULUAN}

Pendidikan merupakan bagian dari kebutuhan primer yang tidak dapat dipisahkan dari kehidupan manusia. Ia juga memiliki fungsi sosial dan memegang peranan yang sangat penting karena dapat membentuk watak dan kepribadian manusia yang berguna bagi kelangsungan hidupnya di tengah masyarakat. Itulah sebabnya dikatakan bahwa pendidikan itu berlangsung sepanjang usia manusia, karena manusia tidak bisa lepas dari proses pendidikan dan pembelajaran.

Dalam sistem pendidikan nasional dinyatakan bahwa pendidikan berfungsi mengembangkan kemampuan dan membentuk watak serta peradaban bangsa yang bermartabat yang bertujuan untuk mengembangkan potensi peserta didik agar menjadi manusia yang beriman dan bertaqwa kepada Tuhan Yang Maha Esa, berakhlak mulia, sehat, berilmu, cakap, kreatif, mandiri, dan menjadi warga negara yang demokratis serta bertanggung jawab. ${ }^{2}$ Di samping muatan pendidikan secara umum, dalam rumusan tujuan di atas juga diarahkan pada pengembangan potensi keagamaan siswa yang perlu dikembangkan dalam budaya pendidikan di sekolah. Hal inilah yang melatari pendidikan agama sebagai mata pelajaran yang wajib bagi semua jenjang pendidikan dari pendidikan dasar sampai pendidikan tinggi yang memiliki peranan dalam membentuk peserta didik menjadi manusia yang beriman dan bertakwa kepada Tuhan Yang Maha Esa serta berakhlak mulia. ${ }^{3}$

Untuk menjadikan materi Pendidikan Agama membumi dalam budaya sekolah dalam bentuk budaya religius perlu didukung dengan kepemimpinan yang efektif untuk menggerakkan segenap sumber daya yang ada yang dimiliki oleh suatu lembaga, sehingga kepemimpinan dapat berfungsi organik dalam proses manajemen. Terkait dengan kepemimpinan di sekolah sebagai suatu organisasi, maka peran seorang pemimpin menjadi bagian penting dari keefektifan lembaga dalam mencapai tujuan yang diharapkan, juga harus mampu memainkan peran strategis dan teknis dalam meningkatkan kualitas sumber daya guru dalam proses belajar mengajar. Dia tidak saja sebagai pemimpin pembelajaran, tapi lebih dari itu adalah sebagai pemimpin secara keseluruhan yang

${ }^{2}$ Undang-Undang SISDIKNAS (Sistem Pendidikan Nasional) Nomor 20 Tahun 2003 Pasal 3 (Jakarta: Sinar Grafika, 2003), hlm. 5-6.

${ }^{3}$ Undang-Undang SISDIKNAS (Sistem Pendidikan Nasional) Nomor 20 Tahun 2003 Penjelasan, hlm. 50. 
mencakup fungsi-fungsi kepemimpinan dalam suatu lembaga sekolah, seperti perencanaan, Pembinaan, Koordinasi dan evaluasi yang didukung dengan keterampilan manajerial dalam menjalankan peran dan fungsi tersebut.

Keterampilan manajerial adalah kemampuan seorang pemimpin untuk melakukan atau menjalankan tugas tertentu dalam lembaga yang dipimpinnya untuk mendapatkan hasil yang berguna. Untuk dapat mencapai tujuan lembaga, seorang manajer ditunutut atau harus mempunyai keterampilan agar dapat menjalankan fungsi-fungsi manajemen yang diperlukan.

Kepala sekolah merupakan pemimpin pendidikan yang memiliki peran sentral dalam membawa keberhasilan lembaga pendidikan karena dia berperan memandu, menuntun, membimbing, membangun, memotivasi kerja, mengemudikan organisasi, menjalin jaringan komunikasi yang baik dengan komunitas sekolah, lingkungan sekitar dan yang lainnya. ${ }^{4}$

Kepemimpinan sebagai salah satu fungsi manajemen merupakan hal yang sangat penting untuk mencapai tujuan organisasi. ${ }^{5}$ Kepemimpinan adalah suatu kekuatan penting dalam rangka pengelolaan, oleh sebab itu kemampuan memimpin secara efektif (effective leader) merupakan kunci keberhasilan organisasi/sekolah.

Seorang pemimpin juga harus mampu menciptakan iklim dan suasana yang kondusif, aman, nyaman, tenteram, menyenangkan, dan penuh semangat dalam bekerja bagi pekerja dan pelajar. Sehingga pelaksanaan kegiatan belajar mengajar dapat berjalan tertib dan lancar dalam mencapai tujuan yang diharapkan. Dengan demikian, setiap kepala sekolah harus mampu mempengaruhi, membimbing, mengkoordinir, dan menggerakkan orang lain yang ada hubungannya dengan pengembangan ilmu pendidikan serta pengajaran supaya aktivitas-aktivitas yang dijalankan dapat lebih efektif dan efisien dalam pencapaian tujuan pendidikan dan pengajaran. ${ }^{6}$

Berdasarkan pengamatan peneliti, pengembangan budaya relegius di SMP Negeri 7 Mataram terlihat berkembang dengan baik, di mana dari heteroginitas budaya, agama, soaial, dan latar lingkungan nampaknya telah dikelola dengan baik, sehingga budaya religius itu sangat terasa di lingkungan sekolah. Siswa-siswinya terlihat sopan, ramah dengan tamu yang datang, dan kegiatan-kegiatan keagamaan dari semua agama yang ada berjalan dengan baik. Demikian pula perayaan hari-hari besar agama berjalan dengan aman dan dalam nuansa toleransi yang tinggi.

Sekalipun di dalam sekolah terdiri dari banyak agama (Islam, Kristen, Hindu, dan bahkan ada yang Budha) namun tidak pernah terjadi benterok atau perkelahian antar agama. Selain latar agama, juga heteroginitas dari latar kehidupan rumah tangga (Dari

\footnotetext{
${ }^{4}$ Hendyat Soetopo, et.al., Kepemimpinan dan Supervisi Pendidikan(Jakarta: Bumi Aksara, 1984), hlm. 1.

${ }^{5}$ Wahjosumidjo, Kepemimpinan, hlm. 5.

${ }^{6}$ Hendyat Soetopo, et.al., Pengantar Operasional Administrasi Pendidikan (Surabaya: Usaha Nasional, 1982), hlm. 271.
} 
perumahan BTN, perkampungan di perkotaaan, dan bahkan dari Pedesaan) bergaul dalam suasana yang damai dan aman.

Kondisi tersebut tidak lepas dari peran kepemimpinan kepala sekolah yang berusaha mengembangkan budaya relegius, sebagaimana hasil perbincangan peneliti dengan beberapa orang guru SMP Negeri 7 Mataram pada tanggal 27 Pebruari 2017 bahwa pengembangan budaya religius di sekolah sangat ditekankan oleh kepala sekolah sebagai upaya penanaman nilai-nilai agama dan moral kepada peserta didik.

Kondisi seperti terurai di atas melatari peneliti untuk mendalami bagaimana Keterampilan Manajerial Kepala Sekolah di SMP Negeri 7 Mataram dalam menciptakan budaya relegius dari kondisi heteroginitas yang ada di dalam warga sekolah, baik dalam komunitas siswa maupun guru dan tenaga administrasi.

Dari latar belakang penelitian di atas, peneliti memfokuskan penelitian pada "Keterampilan Manajerial Kepala Sekolah Dalam Mengembangkan Budaya Relegius di SMP Negeri 7 Mataram." Fokus tersebut dijabarkan dalam beberapa sub fokus sebagai berikut: (1) Bagaimana Realitas budaya releigius yang dikembangkan Kepala Sekolah di SMP Negeri 7 Mataram; (2) Bagaimana Keterampilan Manajerial berupa Keterampilan Konsep kepala sekolah dalam mengembangkan budaya agama di SMP Negeri 7 Mataram; (3) Bagaimana Keterampilan Manajerial berupa Keterampilan manusiawi kepala sekolah dalam mengembangkan budaya agama di SMP Negeri 7 Mataram; (4) Bagaimana Keterampilan Manajerial berupa Keterampilan Teknik kepala sekolah dalam mengembangkan budaya agama di SMP Negeri 7 Mataram; dan (5) Bagaimana Keterampilan Manajerial berupa Keterampilan Personal kepala sekolah dalam mengembangkan budaya agama di SMP Negeri 7 Mataram?

\section{HASIL DAN PEMBAHASAN}

Kepala Sekolah dalam tugasnya sebagai manajer harus mampu mengorganisasikan lembaga dan personil yang bekerja di dalamnya ke dalam situasi yang efektif, demokratis, dan kerjasama. Di bawah kepemimpinannya, semua program harus direncanakan, diorganisir dan ditata sedemikian rupa, termasuk dalam menciptakan suasana sekolah yang religius, dimana SMP Negeri 7 yang terkenal heterogen dari sisi keyakinan dan agama baik tenaga pengajar dan siswanya, menjadi tugas dan tanggung jawab kepala sekolah yang niscaya untuk menciptakan budaya religius.

Berikut akan dibahas temuan-temuan penelitian yang berkaitan dengan Realitas Budaya religius di SMP Negeri 7 Mataram dan beberapa Keterampilan Manaerial Kepala Sekolah dalam menciptakan budaya religius.

\section{Realitas budaya releigius yang dikembangkan Kepala Sekolah di SMP Negeri 7 Mataram}

Budaya relegius di sekolah merupakan starting point untuk menanamkan nilainilai dan aktivitas relegius dalam pola pikir, perilaku, tradisi, kebiasaan, yang dipraktekkan oleh peserta didik, guru, kepala sekolah, dan karyawan di sekolah. 
Pembentukan budaya relegius di SMPN 7 Mataram begitu urgen, mengingat heterogenitas dan pluralitas agama khususnya pada peserta didik relatif tinggi.

Nilai-nilai atau norma-norma menjadi point penting untuk dijadikan acuan atau pedoman bersama dalam kehidupan di sekolah. Ini berarti bahwa nilai-nilai yang telah disepakati bersama dijadikan sebagai pedoman dalam menciptakan atmosfir kehidupan warga sekolah, baik antara kepala sekolah dengan dewan guru, antara guru dengan guru, kepala sekolah dengan peserta didik, guru dengan peserta didik dan antara peserta didik dengan peserta didik. Nilai-nilai dan norma tersebut cukup mewarnai aktivitas seluruh komponen di SMPN 7 Mataram. Nilai toleransi misalnya, seluruh komponen di sekolah ini tampak memiliki sikap saling menghormati dan menghargai antara sesama penganut agama. Pada bulan Ramadlan tahun 1438 H yang baru lalu, susana Ramadlan di sekolah begitu terasa. Guru, karyawan dan peserta didik yang beragama Islam menunaikan ibadah puasa dengan tenang dan damai.

Lantunan ayat-ayat suci al-Qur'an terdengar seperti suara lebah dari mushalla tempat peserta didik muslim membaca dan mengkaji al-Qur'an dengan bimbingan guru. Bagi siswa yang non Muslim menunjukkan rasa hormat dan peduli dengan tidak melakukan aktivitas-aktivitas (makan dan minum di sembarang tempat) yang dapat mengganggu ibadah puasa teman-temannya.

Bahkan saat diadakan buka puasa bersama, seluruh warga sekolah terlibat secara aktif dengan memberikan kontribusi yang telah disepakati bersama oleh seluruh warga sekolah.

Jadi di tengah heterogenitas dan pluralitas agama yang mewarnai kehidupan warga SMPN 7 Mataram, nilai-nilai toleransi tampak teraplikasi dalam perilaku seluruh komponen sekolah termasuk peserta didiknya.

Data yang peneliti dapatkan menunjukkan bahwa suasana penuh toleran yang tergambar di SMPN 7 Mataram terbentuk karena masing-masing warga sekolah telah memahami dengan utuh nilai-nilai yang disepakati sebagai acuan atau pedoman.

Nilai-nilai relegius yang terimplementasi dalam penciptaan suasana atau budaya relegius, beririsan dengan aktivitas regelius. Dalam konteks penelitian ini, aktivitas relegius dimaknai sebagai upaya membudayakan perilaku positif yang didasari oleh nilainilai yang dipedomani dan dapat diamati dalam kehidupan nyata. Atau dengan kata lain aktivitas relegius merupakan upaya menerjemahkan serta mewujudkan nilai-nilai relegius dalam kehidupan nyata. Hal ini dapat dilakukan melalui berbagai kegiatan antara lain: membangun rasa aman, menjaga dan memelihara kebersihan, menata ketertiban, memberikan keteladanan dan keterbukaan.

Nurkholis Majid menjelaskan, bahwa agama bukanlah sekedar tindakan-tindakan ritual seperti sholat dan membaca Al-qur'an serta membaca do'a. Agama lebih dari itu, 
yaitu keseluruhan tingkah laku manusia yang terpuji yang di lakukan dalam kehidupan sehari-hari, yang dilakukan demi memperoleh ridho Allah. ${ }^{7}$

Data hasil penelitian yang bertalian dengan aktivitas relegius di SMPN 7 Mataram, diusahakan melalui penciptaan keamanan, kebersihan, ketertiban, keteladanan dan keterbukaan. Usaha pertama adalah menciptakaan rasa aman bagi seluruh warga sekolah. Keamanan merupakan modal pokok dalam menciptakan suasana yang harmonis dan menyenangkan di sekolah. Keamanan di sini adalah rasa aman dan tenteram serta bebas dari rasa takut, baik lahir maupun batin yang dirasakan oleh seluruh warga sekolah. Suasana sekolah yang aman dan tenteram dapat memotivasi warga sekolah untuk melakukan segala aktivitas dengan baik. Tanpa rasa aman, maka semua kegiatan pendidikan termasuk upaya peningkatan iman dan taqwa peserta didik tidak akan berjalan dengan baik.

Rasa aman yang terjadi di SMPN 7 Mataram diciptakan melalui penataan kondisi sekolah sedemikian rupa, misalnya menempatkan kamera CCTV diberbagai area sekolah terutama di halaman depan dan tempat parkir, selain itu ditempatkan pula satuan pengamanan yang sangat memadai di lingkungan sekolah. Hal ini dimaksudkan untuk mengantisipasi ancaman dan gangguan dari berbagai pihak.

Kebersihan di seluruh lingkungan SMPN 7 Mataram terasa sangat tampak. Suasana bersih, sehat, segar dan nyaman tampak pada seluruh ruang kelas, ruang kerja, kamar mandi, halaman depan dan belakang sekolah, serta fasilitas sekolah lainnya. Bahkan di sekolah ini terpampang dengan sangat jelas larangan merokok di seluruh area sekolah. Budaya bersih yang sangat terasa di sekolah ini merupakan usaha panjang yang dilakukan oleh seluruh komponen sekolah. Hal ini terwujud karena semua komponen sekolah memiliki pemahaman yang sama tentang pentingnya hidup sehat dan sumber daya yang tersedia sangat memadai, baik menyangkut petugas kebersihan maupun alat-alat kebersihannya.

Budaya tertib tampak dengan jelas di SMPN 7 Mataram. Semua warga sekolah menyadari bahwa ketertiban merupakan cerminan keharmonisan dan keteraturan dalam pergaulan antar warga sekolah. Ketertiban ini terimplementasi dalam penggunaan dan pemeliharaan sarana dan prasarana sekolah, penggunaan waktu belajar dan dalam hubungannya dengan masyarakat sekitar. Budaya ini merupakan ikhtiar bersama yang dibangun oleh seluruh warga sekolah dimulai dari lingkungan yang terkecil seperti ruang kelas, perpustakaan, ruang kerja, dan kamar madi atau toilet kemudian meluas ke halaman dalam dan halaman depan sekolah. Ketertiban ini terwujud karena semua perangkat telah memadai seperti tata tertib peserta didik, tata tertib guru dan karyawan.

Kunci utama penciptaan budaya relegius di SMPN 7 Mataram sebagai langkah awal penanaman nilai-nilai keimanan dan ketaqwaan demi terbentuknya sikap toleransi terhadap peserta didik adalah keteladanan. Sangat disadari oleh kepala sekolah, guru dan karyawan, bahwa membangun budaya relegius tidak bisa serta merta dengan menyiapkan

\footnotetext{
${ }^{7}$ Nurkholis Madjid, Masyarakat Religius ( Jakarta: Paramadina, 1997 ), hlm. 91 .
} 
perangkat yang memadai namun jauh lebih penting adalah keteladanan semua pihak. Seluruh warga sekolah, memiliki kewajiban menanamkan nilai-nilai keimanan dan ketaqwaan, tidak merasa cukup dengan hanya mengajarkannya di kelas akan tetapi para guru merasa wajib menyampaikan perannya sebagai sosok yang mampu ditaati dan ditiru oleh peserta didiknya. Itulah mengapa, metode keteladanan ini semakin penting artinya dalam menciptakan budaya relegius di sekolah demi menumbuhkan nilai-nilai keimanan dan ketaqwaan dalam rangka membentuk sikap toleransi peserta didik.

Sementara itu yang bertalian dengan simbul-simbul relegius terimplementasi dalam bentuk tersedianya tempat-tempat ibadah yang layak dan memadai bagi peserta didik yang melaksanakan program imtaq. Di lingkungan sekolah, tersedia sebuah mushalla yang cukup besar dan megah. Mushalla ini sebagai pusat kegiatan ibadah termasuk tempat melaksanakan program imtaq bagi peserta didik yang beragama Islam. Bagi peserta didik yang beragama Kristen dan Budha, tersedia masing-masing sebuah ruang yang relatif memadai. Sementara itu, pelaksanaan program imtaq bagi peserta didik yang beragama Hindu mengambil tempat di sebuah pura di luar lingkungan sekoah. Hal ini menjadi bukti nyata partisipasi aktif masyarakat dalam menyukseskan program imtaq. Bentuk lain simbul-simbul relegius di sekolah ini adalah diwajibkannya seluruh warga sekolah mengenakan pakaian yang menutup aurat, baik putra maupun putri. Bahkan bagi peserta didik putri yang beragama Islam, ada keharusan mengenakan hijab.

Keberagamaan seseorang bisa diwujudkan dalam berbagai sisi kehidupan, Aktifitas agama bukan saja terjadi ketika seseorang melakukan prilaku ritual ( beribadah), tetapi juga ketika melakukan kegiatan lain yang didorong oleh kekuatan supranatural. Bukan hanya berkaitan dengan aktifitas yang tampak dan dapat dilihat dengan mata, tetapi juga aktifitas yang tidak tampak dan terjadi dalam hati seseorang. ${ }^{8}$

Berbagai temuan penelitian di atas tampak dengan nyata, usaha-usaha yang telah dilakukan oleh seluruh komponen-komponen SMPN 7 Mataram dalam mengimplementasikan penciptaan suasana dan budaya relegius yang mendukung pelaksaan program imtaq. Usaha-usaha tersebut antara lain: 1) Menetapkan nilai-nilai yang dijadikan sebagai acuan dalam berprilaku disekolah; 2) Melakukan berbagai aktivitas; dan 3) Menyediakan tempat-tempat ibadah yang layak dan memadai bagi terlaksananya program keagamaan. Seluruh implementasi penciptaan budaya relegius ini diasakan untuk membentuk sikap toleransi peserta didik, baik di lingkungan sekolah, keluarga dan masyarakat.

\section{Keterampilan Konsep kepala sekolah dalam mengembangkan budaya agama di SMP Negeri 7 Mataram}

Keterampilan manajerial berbentuk konsep tentang budaya religius yang dikembangkan oleh kepala sekolah di SMP Negeri 7 Mataram mengacu kepada visi dan

${ }^{8}$ Djamaluddin ancok, Psikologi Islam, Solusi Islam atas problem-problem psikologi(Yogyakarta : Pustaka Pelajar, 1995), hlm. 76. 
misi yang telah disepakati seluruh warga sekolah. Dari konsep visi dan misi itulah dikembangkan konsep-konsep budaya religius oleh kepala sekolah bersama staf guru, Tata Usaha, dan siswa.

Poin penting yang dimaknai sebagai konsep budaya religius di SMP Negeri 7 Mataram adalah bagaimana mewujudkan warga sekolah yang berkarakter, yakni memiliki sikap dan prilaku keagamaan yang dicerminkan lewat bekerja maksimal, jujur, dan siswa yang memiliki sikap dan kepribadian yang baik, peduli, dan sopan. Juga konsep budaya religius itu terlihat dari adanya sikap toleransi diantara warga sekolah, di mana dari segi keyakinan dan kepercayaan, warga SMP Negeri 7 Mataram sangat heterogin.

Apa yang menjadi konsep kepala sekolah terkait budaya religius dalam kenyataannya mengarahkan semua pihak di sekolah untuk melandaskan pemikiran dengan landasan kegamaan sehingga keputusan yang diambil terkait dengan sikap dan prilaku siswa selalu bermuatan moral, kemudian kepedulian kepada sesama juga salah satu konsep yang dikembangkan kepala sekolah sehingga nuansa saling tolong menolong akan selalu nampak dalam heteroginitas agama dan suku di sekolah.

Jadi keterampilan konsep yang dikembangkan kepala sekolah adalah kemampuan mental untuk mengkoordinasikan dan mengintegrasikan seluruh kepentingan dan kegiatan organisasi. Ini mencakup kemampuan manajer untuk melihat organisasi sebagai suatu keseluruhan dan memahami hubungan antara bagian yang saling bergantung, serta menginterpretasikan informasi yang diterima dari bergai macam sumber ${ }^{9}$

Hal penting yang menjadi temuan dalam penelitian ini adalah bahwa di sekolah dicanangkan satu budaya yakni budaya salam dari seluruh warga sekolah sesuai agama dan keyakinan mereka masing-masing, PHBI dan harui besar untuk semua agama yang disupoort dengan maksimal oleh kepala sekolah. Itulah bentuk konsep budaya religius yang dicananghkan oleh kepala sekolah dan berlaku pada semua agama.

Rukun dalam hubungan warga sekolah yang berbeda agama menjadi salah satu bentuk implementasi Konsep Budaya Religius yang dicanangkan oleh Kepala Sekolah. Dengan konsep membangun kerukunan itulah kehidupan warga sekolah dalam heterogenitas akan dapat hidup berdampingan dengan aman dan nyaman.

Keterampilan manusiawi kepala sekolah dalam mengembangkan budaya agama di SMP Negeri 7 Mataram

Membangun hubungan kemanusiaan di tengah-tengah heteroginitas agama memang bukan perkara yang mudah. Seorang Kepala sekolah harus memiliki keterampulan manusiawi yang tercermin dari cara berkomunikasi dan cara bersikap.

Membangun saling pengertian dan saling percaya merupakan konsep yang dipilih oleh Kepala Sekolah dalam implementasi keterampilan manusiawi dalam komunitas yang hlm. 54

${ }^{9}$ Handoko, Hani T. Manajemen Personalia dan Sumber Daya Manusia(Yogyakarta: BPFE, 1996), 
heterogen. Hal ini menjadi paradigram yang tepat menurut kepala sekolah, karena apabila saling pengertian dan saling percaya telah teryanam dalam diri warga sekolah, maka hubungan baik pun akan tercipta diantara mereka sekalipun berbeda keyakinan dan kepercayaan dalam agama.

Kunci utama yang nampak dari pengamatan dan dari apa yang dirasakan oleh warga sekolah dari hasil wawancara di atas, ternyata kepala sekolah dalam membumikan keterampilan manusiawi dalam menciptakan budaya religius adalah perilaku sopan santun terhadap semua warga sekolah baik guru, tata usaha, maupun siswa, sehingga nuansa saling menghargai nampak dalam pergaulan warga sekolah di SMP 7 Mataram.

Kemudian sikap tidak otoriter menjadi pilihan manajerial yang diterapkan Kepala Sekolah. Dengan sikap tidak otoriter itulah kepala sekolah mendahulukan musyawarah dalam segala hal dan gotong royong yang mencerminkan budaya religius berupa saling bantu membantu dalam segala kegiatan, termasuk dalam kegiatan keagamaan baik internal agama maupun antar agama.

Implementasi dari keterampilan manusiawi yang diterapkan Kepala Sekolah dari hasil wawancara dengan Waka Humas adalah komunikasi santun dan pendekatan kekeluargaan. Hal inilah yang menjadikan warga SMP Negeri 7 mengembangkan budaya religius didalam lingkungan sekolah yang heterogen, saling bantu membantu dalam kegiatan keagamaan dan sosial yang dilakukan oleh warga sekolah sekalipun dalam beda agama.

Sebagaimana Steers, dkk menjelaskan:"Human skills involve the ability to work with people. They also require understanding of human motivation and group processes. These skills are necessary for the manager to become involved with and lead his or her work group". ${ }^{10}$

Jadi hubungan baik yang dibangun dalam kepemimpinannya oleh Kepala SMP Negeri 7 Mataram adalah dalam bentuk keakraban diantara atasan dan bawahan tanpa ada sekat atau jarak dan Kepala Sekolah memiliki inisiatif untuk menjadi yang terdepan dalam urusan hubungan sosial kemanusiaan.

Toleransi yang tinggi menjadi point utama Kepala Sekolah dalam menerapkan keterampilan manusiawi di tengah-tengah hetrogenitas warga sekolah, sehingga nuansa religius di tengah-tengah lingkungan sekolah sangat Negeri 7 Mataram.

\section{Keterampilan Teknik kepala sekolah dalam mengembangkan budaya agama di SMP Negeri 7 Mataram.}

Pengorganisasian lembaga dan orang-orang yang berada di dalamnya merupakan bagian dari keterampilan manajerial Kepala sekolah dalam mengelola lembaga yang dipimpinnya. Termasuk didalamnya bagaimana metode atau strategi yang diterapkan Kepala Sekolah dalam mengelola perbedaan agar perbedaan itu bukan menjadi

\footnotetext{
${ }^{10}$ Steers, dkk. Managing Effective Organizations...., hlm. 153
} 
penghalang dalam menciptakan budaya religius akan tetapi menjadi elemen-elemen yang saling memberi energi untuk tercipta nuansa kedamaian dan kenyamanan, terutama dalam bingkai toleransi.

Peringatan hari besar agama-agama di SMP Negeri 7 Mataram menjadi salah satu elemen yang dihidupkan oleh Kepala Sekolah dalam mengembangkan budaya religius agar warga sekolah memahami sekaligus menghargai beberapa macam dan model perayaan hari besar dari agama-agama yang berbeda.

Bersama kita bisa menjadi ikon kepala SMP 7 Mataram dalam mengirganisasikan lembaga dan orang-orang di sekolah. Itulah yang menjadi acuan dalam melaksanakan kegiatan-kegiatan yang bernuansa religius, sehingga dalam kegiatan-kegiatan peringatan hari besar, semua agama ikut berpartisipasi. Hal ini dikuatkan oleh Waka Kurikulum:

Jadi kebersamaan dalam segala macam program dan kegiatan menjadi sangat penting bagi Kepala Sekolah dalam mengayomi berbagai macam perbedaan. Kerjasama adalah strategi yang disambut baik oleh warga SMP Negeri 7 Mataram, karena dengan strategi tersebut perbedaan yang ada tidak nampak dalam pelaksanaan kegiatan, termasuk kegiatan keagamaan.

Di samping strategi kerja sama yang dibangun oleh kepala sekolah, juga ada metode yang membuat strategi tersebut berjalan tanpa kendala. Sebagaimana Hersey (dalam Pidarta) menjelaskan bahwa keterampilan teknis merupakan keterampilan dalam menggunakan pengetahuan, metode, teknik, dan perlengkapan untuk menylesaikan tugas tertentu. Jadi kemampuan teknis itu adalah kemampuan menerapkan pengetahuan atau keahlian khusus yang diperoleh dari pendalaman pengetahuan, keluasan pengalaman, dan kebiasaan mengelola sebuah organisasi. ${ }^{11}$

Ada dua point penting dari metode yang diterapkan kepala sekolah yakni kebersamaan dan open manajemen. Kedua langkah ini menjadi ampuh dalam mengelola perbedaan, karena seluruh warga sekolah merasa diayomi dan merasa terinformasi dalam segal hal termasuk dalam pengelolaan keuangan.

Jadi open manajemen ternyata menjadi unsur penting dalam rangka membangun budaya religius di SMP Negeri 7 Mataram, sehingga seluruh warga sekolah merasa terinformasi tentang kondisi sekolahnya secara keseluruhan yang berimbas kepada hubungan yang baik dan harmonis daintara semua wagra sekolah mulai dari pimpinan hingga clanning service.

\section{Keterampilan Personal kepala sekolah dalam mengembangkan budaya agama di SMP Negeri 7 Mataram}

Dalam upaya mengembangkan suatu program seorang pimpinan selayaknya memiliki keterampilan personal yakni keterampilan yang lahir dari keperibadian yang

\footnotetext{
${ }^{11}$ Pidarta, Made. Manajemen Pendidikan..., hlm. 37
} 
melekat pada diri pimpinan. Keterampilan ini menjadi khas dari seorang pimpinan yang membedakannya dari pemimpin yang lain.

Keterampilan ini menjadi khas oleh karena keterampilan ini berkaitan dengan kesadaran diri, kemampuan menggunakan daya fakir, kecerdasan sosial, relegius dan kesehatan jasmani dan rohani.

Inisiatif yang dilakukan oleh Kepala Sekolah ternyata lahir karena melihat kenyataan di mana warga sekolah memiliki perbedaan yang cukup tinggi dalam hal kepercayaan dan keyakinan. Perbedaan itu kalau tidak dikelola dengan baik, maka tidak menutup kemungkinan akan melahirkan letupan-letupan yang mengganggu kedamaian dan kenyamanan sekolah.

Untuk membuat warga sekolah menerima dengan rasional inisiatif kepala sekolah tersebut, dilakukan sosialisasi lewat kegiatan Imtaq pada semua agama dan budaya senyum, sapa, salam, dan silaturrahmi yang kuat dari seluruh warga sekolah.

Ide budaya religius yang merupakan inisiatif dari kepala sekolah dirasionalisasikan dengan pengakuan UU terhadap agama yang ada di Indonesia melalui penyediaan guruguru agama pada masing-masing agama, sehingga dari sisi spiritual semua agama terlayani.

Visi religius yang diemban oleh SMP Negeri 7 Mataram menjadi sebuah keharusan bagi warga sekolah untuk mewujudkannya dalam bentuk budaya religius dan didukung oleh pimpinan yang memang berlatar religius menjadi sebuah program yang utuh didukung tanpa penolakan dari semua warga sekolah.

Kemudian Program Imtaq menjadi sarana yang cukup penting dalam menjembatani kegiatan keagamaan pada semua agama. Dengan program tersebut kebersamaan, toleransi, kesamaan maksud, dan rasa pengakuan dari semua agama benarbenar terasa. Mulyasa menjelaskan, bahwa kepribadian seorang manajer (Kepala Sekolah) tercermin dalam sifat-sifatnya; jujur, percaya diri, tanggung jawab, berani mengambil resiko dan keput usan, berjiwa besar, emosi yang stabil, dan teladan. ${ }^{12}$

Di samping rasionalisasi budaya religius melalui kegiatan imtaq keagamaan, juga melalui penguatan elemen-elemen agama dalam bentuk ekstrakurikuler yang dikelola oleh guru agama masing-masing.

\section{SIMPULAN}

Dari hasil penelitian yang dilakukan melalui kegiatan wawancara, pengamatan, dan dokumentasi terkait dengan Keterampilan Manajerial Kepala Sekolah di SMP Negeri7 Mataram, dapat disimpulkan sebagai berikut:

Realitas budaya releigius yang dikembangkan Kepala Sekolah di SMP Negeri 7 Mataram tercermin pada: (1) Nilai-nilai atau norma-norma cukup mewarnai aktivitas

\footnotetext{
${ }^{12}$ E. Mulyasa,Menjadi Kepala Sekolah Profesional (Bandung: Remaja Rosda Karya, 2005), hlm. 24
} 
seluruh komponen di SMPN 7 Mataram; (2) Nilai toleransi. Seluruh komponen di sekolah tampak memiliki sikap saling menghormati dan menghargai antara sesama penganut agama; (3) Terciptanya rasa aman bagi seluruh warga sekolah. Keamanan merupakan modal pokok dalam menciptakan suasana yang harmonis dan menyenangkan di sekolah; (4) Budaya tertib tampak dengan jelas di SMPN 7 Mataram. Semua warga sekolah menyadari bahwa ketertiban merupakan cerminan keharmonisan dan keteraturan dalam pergaulan antar warga sekolah; dan (5) Tersedianya tempat-tempat ibadah yang layak dan memadai bagi peserta didik yang melaksanakan program imtaq.

Sementara Keterampilan Konsep kepala sekolah dalam mengembangkan budaya agama di SMP Negeri 7 Mataram dapat dililihat dari program yang yang direncanakan Kepala Sekolah antara lain: (1) Membangun karakter, yakni memiliki sikap dan prilaku keagamaan yang dicerminkan lewat bekerja maksimal, jujur; (2) Menempa siswa agar memiliki sikap dan kepribadian yang baik, peduli, dan sopan; (3) Memacu warga sekolah untuk peduli kepada sesama yang dikembangkan kepala sekolah sehingga nuansa saling tolong menolong akan selalu nampak dalam heteroginitas agama dan suku di SMP Negeri 7 Mataram; dan (4) Menanamkan kebiasaan salam bagi siswa.Nampak budaya salam dari siswa dan tegur sapa dengan selamat pagi kepada guru dan tamu yang datang.

Di samping keterampilan konsep, Kepala SMP Negeri 7 Mataram juga menerapkan keterampilan manusiawi dalam mengembangkan budaya agama di SMP Negeri 7 Mataram, antara lain: (1) Kepala sekolah menanamkan saling pengertian dan saling percaya telah dalam diri warga sekolah, sehingga hubungan baik pun tercipta diantara mereka sekalipun berbeda keyakinan dan kepercayaan dalam agama; (2) Mengedepankan perilaku sopan santun pada semua warga sekolah baik guru, tata usaha, maupun siswa; (3) Membiasakan komunikasi santun dan pendekatan kekeluargaan; dan (4) Menciptakan suasana keakraban diantara atasan dan bawahan tanpa ada sekat atau jarak dan Kepala Sekolah memiliki inisiatif untuk menjadi yang terdepan dalam urusan hubungan sosial kemanusiaan.

Yang mendukung keberhasilan kepala sekolah dalam mengembangkan budaya religius di samping keterampilan di atas adalah Keterampilan Teknik dalam mengembangkan budaya agama di SMP Negeri 7 Mataram yang nampak dari kegiatankegiatan yang dijalankan: (1) Peringatan hari besar agama-agama di SMP Negeri 7 Mataram menjadi salah satu elemen yang dihidupkan oleh Kepala Sekolah dalam mengembangkan budaya religius agar warga sekolah memahami sekaligus menghargai beberapa macam dan model perayaan hari besar dari agama-agama yang berbeda; (2) Kebersamaan dalam segala macam program dan kegiatan menjadi sangat penting bagi Kepala Sekolah dalam mengayomi berbagai macam perbedaan; (3) Menghargai satu sama lain adalah cara yang dikedepankan kepala sekolah dalam mengelola perbedaan yang ada didalam warga sekolah; dan (4) Open manajemen ternyata menjadi unsur penting dalam rangka membangun budaya religius di SMP Negeri 7 Mataram. 
Sebagai kepala sekolah yang menjadi top leaderharus mampu menciptakan hubungan yang harmonis di tengah-tengah heteroginitas warga sekolah yang dipimpinnya yang harus diimplementasikan dalam bentuk Keterampilan Personal dalam mengembangkan budaya religius seperti yang dilakukan kepala SMP 7 Mataram: (1) Ide budaya religius yang merupakan inisiatif dari kepala sekolah dirasionalisasikan dengan pengakuan UU terhadap agama yang ada di Indonesia; (2) Visi religius yang diemban oleh SMP Negeri 7 Mataram menjadi sebuah keharusan bagi warga sekolah untuk mewujudkannya dalam bentuk budaya religius; dan (3) Rasionalisasi budaya religius melalui kegiatan imtaq keagamaan, juga melalui penguatan elemen-elemen agama dalam bentuk ekstrakurikuler yang dikelola oleh guru agama masing-masing.

\section{DAFTAR PUSTAKA}

Afifuddin dan Beni Ahmad Saebani, Metodologi Penelitian Kualitatif(Bandung: Pustaka Setia, 2012)

Depdiknas. Pengembangan Model Pendidikan Kecakapan Hidup (Jakarta: Pusat Kurikulum Badan Penelitian dan Pengembangan Depdiknas, 2003)

Djamaluddin ancok, Psikologi Islam, Solusi Islam atas problem-problem psikologi (Yogyakarta : Pustaka Pelajar, 1995)

E. Mulyasa, Menjadi Kepala Sekolah Profesional (Bandung: Remaja Rosda Karya, 2005)

Handoko, Hani T. Manajemen Personalia dan Sumber Daya Manusia (Yogyakarta: BPFE, 1996)

Hendyat Soetopo, et.al., Kepemimpinan dan Supervisi Pendidikan (Jakarta: Bumi Aksara, 1984)

Hendyat Soetopo, et.al., Pengantar Operasional Administrasi Pendidikan (Surabaya: Usaha Nasional, 1982)

Ignas, F.E., Edward, Roymund, J., Cosini. Comparative Educational Systems Itasca (Illionis: F.E. Peacock Publishers. Inc., . 1975)

John W. Creswell, Qualitative Inquiry and Research Design: Choosing Among Five Traditions (California: Sage Publication, Inc., 1998)

Matthew B. Miles dan A. Michael Huberman. Analisis Data Kualitatif terjemahan Rohidid Tj. R. (Jakarta: Universitas Indonesia, 1992)

Muhaimin, Paradigma Pendidikan Islam : Upaya mengektifkan Pendidikan Agama Islam di Sekolah ( Bandung : Rosdakarya, 2001)

Nurkholis Madjid, Masyarakat Religius ( Jakarta: Paramadina, 1997 )

Pidarta, Made. Manajemen Pendidikan di Indonesia (Jakarta : Rineka Cipta, 2004)

QS. Al-Baqarah ayat, 208 
Steers, dkk. Managing Effective Organizations An Introduction (Boston :Kent Publishing Company, 1985)

Sugiyono, Metode Penelitian Pendidikan: Pendekatan Kuantitatif, Kualitatif dan R\&D (Bandung: Alfabeta, 2008)

Undang-Undang SISDIKNAS (Sistem Pendidikan Nasional) Nomor 20 Tahun 2003 Pasal 3 (Jakarta: Sinar Grafika, 2003) 